\title{
Culture of epithelial and stromal cells of guinea-pig endometrium and the effect of oestradiol-17 $\beta$ on the epithelial cells
}

\author{
G. Chaminadas, A. Y. Propper, M. Royez, O. Prost, J. P. Remy-Martin and \\ G. L. Adessi \\ Unité de Recherches de Biochimie Hormonale et des Régulations, INSERM U 198, route de Dole, \\ 25000 Besançon, France
}

\begin{abstract}
Summary. Epithelial and stromal cells of guinea-pig endometrium were separated by enzymic digestion, isolated by successive centrifugation, and maintained in culture as pure cell types for 5 days on growth medium. On Day 5, ultrastructural studies were performed on the two cell types, demonstrating that epithelial cells can grow as a monolayer composed of cohesive groups of polygonal cells $\left(1 \cdot 3 \times 10^{5} \mathrm{cells} / \mathrm{cm}^{2}\right)$, while stromal cells were mostly fibroblastic. The effect of hormones was studied on the epithelial cells in culture. The monolayer was cultured into harvest medium for 3 days to ensure the complete removal of endogenous steroids, then these cells were incubated with $2 \times 10^{-9} \mathrm{M}$-oestradiol-17 $\beta$ for 3 days. There was a rise in the progesterone receptor level, varying from $1 \cdot 3$ to $10 \cdot 8$ times. The three enzymes known to interfere with oestradiol-17 $\beta$ metabolism were present in the epithelial cells grown in our culture conditions. By incubation with oestrone sulphate for 3 days it was demonstrated that, in cultured epithelial cells, (1) oestrone sulphate is converted into oestradiol-17 $\beta$ sulphate, and (2) oestrogen sulphates are hydrolysed to active oestrogens.
\end{abstract}

\section{Introduction}

In-vitro culture methods offer a powerful tool for direct studies of hormonal actions on endometrium in well defined conditions that otherwise could not be obtained by in-vivo experimentation. Two kinds of in-vitro systems have been developed for the study of steroid action on endometrial tissues.

Uterine explants in organ culture have been used, preserving uterine morphology and histological differentiation. Kaufman et al. (1980) have described an organ culture method for human endometrium, Shapiro, Dyer \& Colas (1980) have used an organ culture system to evaluate the response of human proliferative endometrium to progesterone stimulation, Clarke, Adams \& Wren (1982) have established that progesterone induces 17 $\beta$-hydroxysteroid dehydrogenase in this human culture system, and Chaminadas, Prost, Propper, Agnani \& Adessi (1982) have measured the steroid sulphatase activities in human endometrium grown in organ culture. Adler, Alberghini, Counts \& Auletta (1983) have studied the secretion of mucin by explants of rabbits and human cervix in organ culture, and Sumida, Gelly \& Pasqualini (1983) have established an organ culture system for fetal uterus of guinea-pig to study the control of progesterone receptor induction. Cell cultures appear preferable when the aim is to determine how hormones regulate the cellular differentiation of the endometrium. Eckert \& Katzenellenbogen (1981) have grown a primary culture of human endometrium containing both epithelial and stromal cells which are hormoneresponsive; other authors have used human endometrium cell cultures after separation of two cellular types for hormonal and metabolic studies (Satyaswaroop, Fleming, Bressler \& Gurpide, 
1978; Fleming \& Gurpide, 1981; Korte, MacDonald, Johnston, Janice \& Casey, 1983; Tseng, 1984). Rajkumar, Bigsby, Lieberman \& Gerschenson (1983) have obtained uteroglobin production by rabbit epithelial cell culture, but the health and cellular type of the cells was not checked ultrastructurally. Morphological characteristics and hormonal studies have been carried out together by Bell \& Searle (1981) who studied the differentiation of decidual cells in mouse endometrium, by Ricketts, Hagensee \& Bullock (1983) investigating uteroglobin production by the two cellular types of rabbit endometrium in culture, by Echeverria, Vazquez-nin \& Pedron (1980) studying the response of rat endometrium to oestradiol-17 $\beta$ in culture, by Siegfried, Nelson, Martin \& Kaufman (1984) for histochemical identification of cultured cells from human endometrium and by McCormack \& Glasser (1980) who cultured separately epithelial, stromal and myometrial cells of rat uterus and studied the response of each cellular type to oestradiol-17 $\beta$ in vitro. Until now such studies have not been reported on guinea-pig endometrium.

The effects of oestrogen on guinea-pig endometrium have been reported by Sumida et al. (1983) and Lanzone, Nguyen \& Pasqualini (1983) who described an hormonal control of the progesterone receptor synthesis in the fetal uterus. Laure \& Pasqualini (1983) have demonstrated that oestradiol-17 $\beta$ increased the RNA polymerase in fetal uterus. Moutaouakkil, Prost, Dahan \& Adessi (1984) have studied sulphatase activities in the uterus, and a metabolic pathway of oestrogens in pregnant female guinea-pigs has been proposed (Adessi, Tran Quang Nhuan \& Prost, 1981; Adessi, Tran Quang Nhuan \& Vingler, 1982).

In the present study, we have developed epithelial and stromal cell primary cultures of guinea-pig endometrium, and characterized their ultrastructural features in transmission and scanning electron microscopy. Then, the culture conditions for the study of oestrogen action on progesterone receptor induction and oestradiol-17 $\beta$ and oestrone sulphate metabolism in this epithelial cell culture system were determined.

\section{Materials and Methods}

Chemicals and reagents. CMRL 1066 medium, Hank's Balanced Salt Solution (HBSS), $\mathrm{Ca}^{2+}$ - and $\mathrm{Mg}^{2+}$-free HBSS (CMF-HBSS), penicillin, streptomycin, gentamycin, fungizone, Hepes buffer, fetal calf serum (FCS) and horse serum were obtained from Flow Laboratories (Puteaux, France). A steroid-free serum substitute (Ultroser SF) was obtained from IBF (Villeneuve la Garenne, France). Oestradiol-17 $\beta$, oestrone-3-sulphate, dehydroepiandrosterone-3-sulphate (DHEA sulphate), diethylstilboestrol, cortisol, dithiothreitol and ethylenediamine tetracetic acid (EDTA) were purchased from Sigma Chemical Co. (St Louis, MO, U.S.A.). $\left[6,7-{ }^{3} \mathrm{H}\right]$ Oestrone sulphate (ammonium salt) (sp. act. $53 \cdot 0 \mathrm{Ci} / \mathrm{mmol}$ ), $\left[7-{ }^{3} \mathrm{H}\right] \mathrm{DHEA}$ sulphate (ammonium salt) (sp. act. $24.0 \mathrm{Ci} / \mathrm{mmol}$ ), $\left[4-{ }^{14} \mathrm{C}\right] \mathrm{DHEA}$ (sp. act. $57 \cdot 8 \mathrm{mCi} / \mathrm{mmol}$ ), [methyl-3- $\left.{ }^{3} \mathrm{H}\right] \mathrm{R} 5020$ (sp. act. $80 \mathrm{Ci} / \mathrm{mmol}$ ) and unlabelled R 5020 were obtained from New England Corporation (Boston, MA, U.S.A.). $\left[2,4,6,7-{ }^{3} \mathrm{H}\right]$ Oestradiol-17 $\beta$ (sp. act. $100 \cdot 0 \mathrm{Ci} / \mathrm{mmol}$ ) was purchased from the Commissariat à l'Energie Atomique (Gif sur Yvette, France). $\left[4-{ }^{14} \mathrm{C}\right]$ Oestrone (sp. act. $52.0 \mathrm{mCi} / \mathrm{mmol}$ ) was obtained from the Radiochemical Centre (Amersham, U.K.).

Preparation of guinea-pig endometrial cell cultures and culture conditions. Guinea-pigs, weighing $400-500 \mathrm{~g}$, of the Hartley albino variety, were purchased from the Centre de Zootechnie Coblanbel (Montmédy, France). The animals were maintained under controlled temperature $\left(20^{\circ} \mathrm{C}\right)$ and lighting conditions ( $12 \mathrm{~h}$ light: $12 \mathrm{~h}$ dark). They were fed ad libitum with standard food enriched with ascorbic acid. Uteri were removed from mature virgin females killed on the day of vaginal opening, and placed in sterile HBSS containing penicillin $(1000 \mathrm{U} / \mathrm{ml})$, streptomycin $(1000 \mu \mathrm{g} / \mathrm{ml})$, and $10 \mathrm{~mm}$-gentamycin buffered to $\mathrm{pH} 7.4$ with 20 mM-Hepes. All procedures were conducted under sterile biological conditions. The myometrium was torn off, then the endometrium was minced into $2.5 \mathrm{~mm}$ cubes and washed three times in sterile CMF-HBSS containing streptomycin $(100 \mu \mathrm{g} / \mathrm{ml})$, penicillin $(100 \mathrm{U} / \mathrm{ml})$ and buffered to $\mathrm{pH} 7 \cdot 4$ with $20 \mathrm{mM}-$ Hepes. 
Cells were dissociated according to the method of Satyaswaroop, Bressler, de la Pena \& Gurpide (1979) as modified by Varma et al. (1982). The endometrial fragments were incubated in $0.25 \%(\mathrm{w} / \mathrm{v})$ collagenase, dissolved in CMF-HBSS buffered to $\mathrm{pH} 7.4$ with $20 \mathrm{~mm}$-Hepes, for $2 \mathrm{~h}$ at $37^{\circ} \mathrm{C}$. The cell dissociation was monitored by phase-contrast microscopy. After dissociation, the undigested fragments were collected by sedimentation. The glands and the supernatant cell suspension were centrifuged at $100 \mathrm{~g}$ for $5 \mathrm{~min}$. The pellet containing epithelial glands was washed three times in $5 \mathrm{ml} \mathrm{CMF-HBSS}$ then centrifuged at $100 \mathrm{~g}$ for $5 \mathrm{~min}$. The remaining pellet containing approximately $95 \%$ of glandular epithelial cells was plated in the growth culture medium (see below), $10^{3}$ epithelial cell clusters per $\mathrm{ml}$ (in $25 \mathrm{~cm}^{2}$ tissue culture flasks; Falcon). After gland isolation, the supernatant was centrifuged at $400 \mathrm{~g}$ for $10 \mathrm{~min}$, then the pellet containing the stromal cells was plated in growth culture medium $\left(10^{5}\right.$ cells $\left./ \mathrm{ml}\right)$.

The growth culture medium was CMRL 1066 supplemented with 10\% FCS, penicillin $(100 \mathrm{U} / \mathrm{ml})$, streptomycin $(100 \mu \mathrm{g} / \mathrm{ml})$, fungizone $(2.5 \mu \mathrm{g} / \mathrm{ml}), 10 \mathrm{~mm}-\mathrm{L}-$ glutamine, glucose $(5 \mathrm{mg} / \mathrm{ml})$, insulin $(5 \mu \mathrm{g} / \mathrm{ml}), \quad \mathrm{NaHCO}_{3}(0.85 \mathrm{mg} / \mathrm{ml}), \quad 20 \mathrm{mM}-\mathrm{Hepes}$ buffer and $10^{-9} \mathrm{M}-$ oestradiol-17 $\beta$. The flasks were incubated in a humidified atmosphere composed of $5 \% \mathrm{CO}_{2}$ and $95 \%$ air.

The plated cultures reached confluence within 5-6 days. The medium was changed every 3 days. For experiments, after 5-6 days the growth medium was replaced by fresh harvest medium: CMRL 1066, penicillin $(100 \mathrm{U} / \mathrm{ml})$, streptomycin $(100 \mu \mathrm{g} / \mathrm{ml})$, fungizone $(2.5 \mu \mathrm{g} / \mathrm{ml}), 10 \mathrm{~mm}$-L-glutamine, glucose $(5 \mathrm{mg} / \mathrm{ml})$, insulin $(5 \mu \mathrm{g} / \mathrm{ml}), \mathrm{NaHCO}_{3}(0.85 \mathrm{mg} / \mathrm{ml}), 20 \mathrm{mM}-\mathrm{Hepes}$ and $10 \% \mathrm{FCS}$ pretreated with dextran-charcoal, $2 \cdot 5 \%$ horse serum or $2 \%$ Ultroser SF.

- To ensure the complete removal of endogenous steroids, the harvest medium was changed every day for 3 days, and the concentrations of oestradiol-17 $\beta$, oestrone and oestrone sulphate in the medium were measured each day.

To stimulate progesterone receptor synthesis, the cells were cultured 3 more days in fresh harvest medium supplemented with $2 \times 10^{-9} \mathrm{M}$-oestradiol-17 $\beta$, then harvested and processed for biochemical studies. Oestrone sulphate metabolism was studied in epithelial cells cultured during 3 days in harvest medium containing $10^{-7} \mathrm{M}$-oestrone sulphate renewed each day. On Day 3, unconjugated and conjugated oestrogens were identified by mass-spectrometry in the harvest culture medium.

The growth of the monolayers was followed daily with an Olympus T 01 inverted phasecontrast microscope. For examination by scanning electron microscopy, the cell cultures were carefully rinsed and fixed in $0.1 \mathrm{M}$-sodium cacodylate-buffered $2 \%$ glutaraldehyde, $\mathrm{pH} 7 \cdot 4$, for $30 \mathrm{~min}$. After dehydration with acetone, the specimens were transferred into liquid $\mathrm{CO}_{2}$ for critical-point drying. Sputter-coated pieces of cell culture were viewed in an Autoscan Etec scanning electron microscope (Siemens, St Denis, France).

For electron microscopy, the cells were cultured on coverslips, then fixed in $0.1 \mathrm{M}$-sodium cacodylate-buffered $2 \%$ glutaraldehyde, $\mathrm{pH} 7 \cdot 4$, for $30 \mathrm{~min}$, washed in the same buffer and postfixed in $0.1 \mathrm{M}$-sodium cacodylate-buffered $1 \%$ osmium tetroxide, $\mathrm{pH} 7.4$. After dehydration in ethanol, the specimens were embedded in Epon by inverting filled capsules over them. Ultrathin sections were stained with uranyl acetate and lead citrate, cut perpendicularly to the culture surface, examined and photographed with an Elmiskop 101 electron microscope (Siemens).

Hormone assay in incubating medium. Commercial RIA kits purchased from BioMerieux (Lyon, France) were used for determination of oestradiol and oestrone according to the manufacturer's procedures. Oestrone sulphate was measured using a specific method developed in our laboratory by Remy-Martin, Prost, Nicollier, Burnod \& Adessi (1983). Briefly, free steroids were extracted from plasma with diethyl ether and steroid sulphates were isolated with use of Vlitos' reagent (methylene blue in dilute $\mathrm{H}_{2} \mathrm{SO}_{4} / \mathrm{Na}_{2} \mathrm{SO}_{4}$ solution). After enzymic hydrolysis, oestrone was isolated by chromatography on Celite and measured by radioimmunoassay. The intra- and inter-assay coefficients of variation were $9 \cdot 7 \%$ and $10 \cdot 5 \%$ respectively. No cross-reaction was found with free 
oestrogens or with oestrone glucuronide. The limit of sensitivity for this technique was equal to $23 \cdot 2 \mathrm{fmol}$ per tube.

Oestrone and dehydroepiandrosterone sulphatase assays. After culture, the epithelial cells were removed from the flasks by scraping, centrifuged at $400 \mathrm{~g}$, then frozen in liquid nitrogen before enzyme studies. The method for oestrone and DHEA sulphatase assays has been described previously by Prost \& Adessi (1983). Briefly, the cell pellets were resuspended in $0.05 \mathrm{M}$-Tris- $\mathrm{HCl}, 0.25 \mathrm{M}$ saccharose buffer, $\mathrm{pH} 7 \cdot 0$, and homogenized with a Potter-Elvehjem instrument. The homogenate was centrifuged at $12500 \mathrm{~g}$ for $20 \mathrm{~min}$ at $4^{\circ} \mathrm{C}$. The sulphatase activities were measured in $0.05 \mathrm{M}$-Tris- $\mathrm{HCl}$ buffer, $\mathrm{pH} 7.6$, containing $\left[{ }^{3} \mathrm{H}\right]$ oestrone sulphate (sp. act. $34 \mathrm{nmol} / \mathrm{ml}$; $24 \times 10^{3}$ d.p.m. $/ \mathrm{nmol}$ ) or $\left[{ }^{3} \mathrm{H}\right]$ DHEA sulphate $\left(\mathrm{sp}\right.$. act. $60 \mathrm{nmol} / \mathrm{ml} ; 15 \times 10^{3}$ d.p.m. $/ \mathrm{nmol}$ ) in a final volume of $0.5 \mathrm{ml}$. The reaction was started by adding the $12500 \mathrm{~g}$ supernatant $(0 \cdot 10 \mathrm{mg}$ protein per assay) and stopped after $30 \mathrm{~min}$ at $37^{\circ} \mathrm{C}$ by adding $1 \mathrm{ml} 0 \cdot 1 \mathrm{M}-\mathrm{Na}_{2} \mathrm{CO}_{3} \cdot\left[{ }^{14} \mathrm{C}\right]$ Oestrone or $\left[{ }^{14} \mathrm{C}\right] \mathrm{DHEA}$ (2000 d.p.m.) was added to correct methodological losses and unconjugated oestrone and DHEA were extracted with $5 \mathrm{ml}$ diethyl ether or $4 \mathrm{ml}$ petroleum benzine GR (Merck) respectively. Controls without enzyme preparation were processed simultaneously, and the minute amount of radioactivity recovered in the unconjugated fraction was subtracted from that of the experimental assay. One unit of sulphatase activity was defined as the quantity of the enzyme preparation producing one pmol of product per minute per mg DNA. The analytical criteria for oestrone and DHEA sulphatase activities in endometrium have been previously reported (Prost \& Adessi, 1983). Precision values were $6.0 \%$ and $11.3 \%$ respectively. The assay blank (non-specific hydrolysis) was $<1 \%$ of the incubated radioactivity.

The DNA assay was performed according to the method of Burton (1956).

Dextran charcoal assays of cytosolic oestradiol and progesterone receptors. The method for receptor assays has been described previously by Moutaouakkil et al. (1984). The epithelial cell pellets were homogenized in ice-cold buffer composed of $10 \mathrm{~mm}$-Tris-HCl, $1.5 \mathrm{~mm}$-EDTA, $0.5 \mathrm{~mm}$-dithiothreitol, $10 \mathrm{mM}$-sodium-molybdate and $10 \%$ glycerol (v/v) (TEDM-glycerol buffer, $\mathrm{pH} 7 \cdot 4)$. The homogenate was centrifuged at $4^{\circ} \mathrm{C}$ at $105000 \mathrm{~g}$ for $60 \mathrm{~min}$, using a Beckman model L8-55 ultracentrifuge equipped with a 70-1 Ti rotor. The supernatant was diluted with TEDMglycerol to a final concentration of $\sim 2 \mathrm{mg}$ protein per $\mathrm{ml}$. For oestradiol receptors, the aliquants of cytosol were incubated for $1 \mathrm{~h}$ at $0^{\circ} \mathrm{C}$ with $5 \mathrm{~nm}-\left[{ }^{3} \mathrm{H}\right]$ oestradiol-17 $\beta$, with or without a 100 -fold excess of unlabelled diethylstilboestrol. Bound and free oestradiol-17 $\beta$ were separated by adding $200 \mu \mathrm{l}$ of ice-cold dextran-coated charcoal suspension in TEDM-glycerol buffer, followed by an incubation of $30 \mathrm{~min}$ with constant stirring. After centrifugation at $4050 \mathrm{~g}$ for $10 \mathrm{~min}$ at $0^{\circ} \mathrm{C}$, an aliquant of supernatant was used to measure the radioactivity.

A similar procedure was used for the determination of progesterone binding sites: $20 \mathrm{~nm}-\left[{ }^{3} \mathrm{H}\right] \mathrm{R} 5020$ served as radioactive ligand and unspecific binding was measured by adding a 100 -fold excess of unlabelled R 5020. After addition of $10 \mu \mathrm{M}$-cortisol and incubation for $4 \mathrm{~h}$ at $0^{\circ} \mathrm{C}$ with constant stirring, the aliquants were treated by the charcoal-dextran solution and centrifuged at $4050 \mathrm{~g}$ for $10 \mathrm{~min}$ at $0^{\circ} \mathrm{C}$, then an aliquant of supernatant was used to measure the radioactivity. The assay of receptors was made in triplicate for each culture sample because the amount of available proteins was not sufficient to establish Scatchard plots. Negative controls with intestinal tissue demonstrated the specificity of $\left[{ }^{3} \mathrm{H}\right]$ oestradiol- $17 \beta$ and $\left[{ }^{3} \mathrm{H}\right] \mathrm{R} 5020$ binding to hormone receptors. When the values were below $10 \mathrm{fmol}$ per mg protein the assay was judged as negative. The intraand inter-assay coefficients of variation were $4 \cdot 3 \%$ and $8 \cdot 6 \%$ respectively $(n=12)$.

Free and sulphoconjugated steroid assays by gas chromatography-mass spectrometry. The method has been described previously by Adessi et al. (1982). The mass-spectrometer used was a RIBER R 10-10 B (Ribermag, Rueil, France) coupled with a gas-chromatograph GIRDEL 30 (Girdel, Puteaux, France) equipped with a SE-300.2 mm open tubular fused-silica capillary column. 


\section{Results}

\section{Morphological results}

The appearance and growth characteristics of the two cell types in culture were studied. Phasecontrast microscopy revealed a good separation and isolation of the epithelial from the stromal celis. The epithelial component comprised glandular structures composed of several hundred cells (10 $\mu \mathrm{m}$ in diameter) (Fig. 1a), whereas the stromal component was composed of isolated cells (5-15 $\mu \mathrm{m}$ in diameter) which attached to the plastic surface within $30 \mathrm{~min}$ (Fig. Ib).
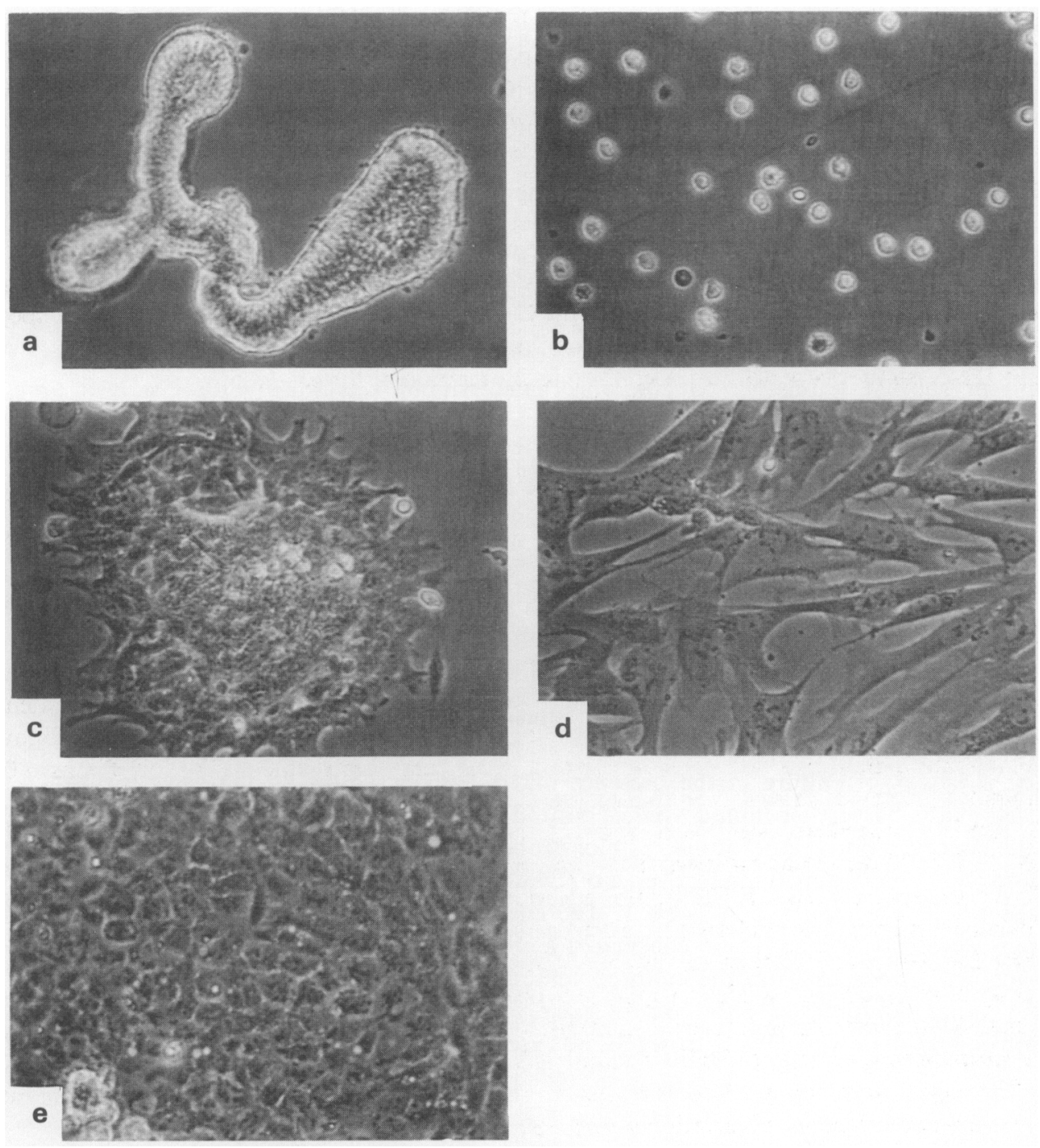

Fig. 1. Phase-contrast microphotographs of the two endometrial cell types in culture. $\times 200$. (a) Epithelial gland immediately after cell isolation; (b) stromal cells immediately after cell isolation; (c) an epithelial gland adhering to the bottom of the flask after $48 \mathrm{~h}$ in growth medium; (d) stromal cells at $48 \mathrm{~h}$; (c) epithelial cells growing as monolayers composed of cohesive groups of polygonal cells on Day 5 . 
During the first $48 \mathrm{~h}$ after plating, the epithelial glands adhered progressively to the bottom of the flasks (Fig. lc). The plating efficiency seemed to depend on the integrity of the glands after digestion by collagenase. The morphology of the stromal cells was mostly fibroblastic and they rapidly reached confluence in all the flasks (Fig. 1d).

After 5 days, the epithelial cells grew as monolayers composed of cohesive groups of polygonal cells $\left(1.3 \times 10^{5} \mathrm{cells} / \mathrm{cm}^{2}\right)$ on which our biochemical experiments were performed (Fig. 1e).

To confirm their structural appearance, epithelial and stromal cell cultures were examined after 5 days in vitro by scanning and transmission electron microscopy respectively. In the scanning electron microscope study, the epithelial cells appeared cohesive, with a circular nucleus and microvilli were scattered over their surface (Fig. 2a). The stromal cells were elongated, and large intercellular spaces were seen between the cells (Fig. 2b).

In ultrathin sections, cut perpendicularly to the monolayer surface, the shape of the epithelial cells appeared pyramidal, with a centrally located nucleus, and cytoplasmic cell processes extending peripherally (Fig. 2c). In places, the adjacent cells contacted each other by means of membrane interdigitations. Numerous microvilli were present at the upper surface of the cells; their cytoplasm contained few mitochondria, numerous polysomes and an abundant rough endoplasmic reticulum, while their nuclei appeared circular with a condensed chromatin and active nucleoli. These morphological results showed that the endometrial specific differentiation occurred in the epithelial cells cultured in the presence of oestradiol-17 $\beta$.

The cells recovered in the supernatant obtained after centrifugation of the product of endometrium digestion by collagenase displayed a typical fibroblastic morphology in culture (Fig. $2 \mathrm{~d}$ ). These cells were elongated in shape and grew as a monolayer or multilayered sheaths. Their cytoplasm showed a relative paucity of organelles, but was filled with glycogen granules, microfilaments and lipid droplets. Their nucleus was elongated with a peripheral condensed chromatin.

These results demonstrated that it is possible to culture separately epithelial and stromal cells from guinea-pig endometrium. These cells remain recognizable as uterine cells at the microscopic and ultrastructural levels by their appearance and structure. For 39 assays of epithelial cell culture, 36 yielded a monolayer cell culture after 5 days.

\section{Metabolism of oestrogens by epithelial cells in culture}

To test the effect of oestradiol-17 $\beta$ on endometrial cells, it was important to obtain viable cells in an oestrogen-free culture medium.

After 5 days of culture in the presence of $10^{-9} \mathrm{M}$-oestradiol- $17 \beta$ the growth medium was replaced by the harvest medium devoid of oestradiol- $17 \beta$ which was changed every day for 3 days and the concentrations of oestradiol-17 $\beta$, oestrone and oestrone sulphate were measured in fresh medium and in harvest medium recovered on Days 1,2 and 3 of the culture.

The results are reported in Table 1. The concentrations of oestrogens in the fresh harvest medium were very low and were considered as the control values. On Day 1, due to release of endogenous oestrogens from the cultured cells, the highest values were found. On Day 3, the steroid values had returned to the control levels. Identical values were obtained with an assay performed on Day 4 , or when $2 \%$ Ultroser SF was used instead of $2.5 \%$ horse serum. However, after 3

Fig. 2. Ultrastructural observations on the two types of endometrial cells after 5 days culture in growth medium. (a) Scanning electron micrograph of epithelial cells, $\times 1400$; (b) scanning electron micrograph of stromal cells, $\times 1400$; (c) transmission electron micrograph of an epithelial cell, $\times 5000$; (d) microvilli, $\times 26000$; (e) transmission electron micrograph of stromal cells, $\times 5000 ;(f)$ glycogen granules and microfilaments, $\times 19000$. 

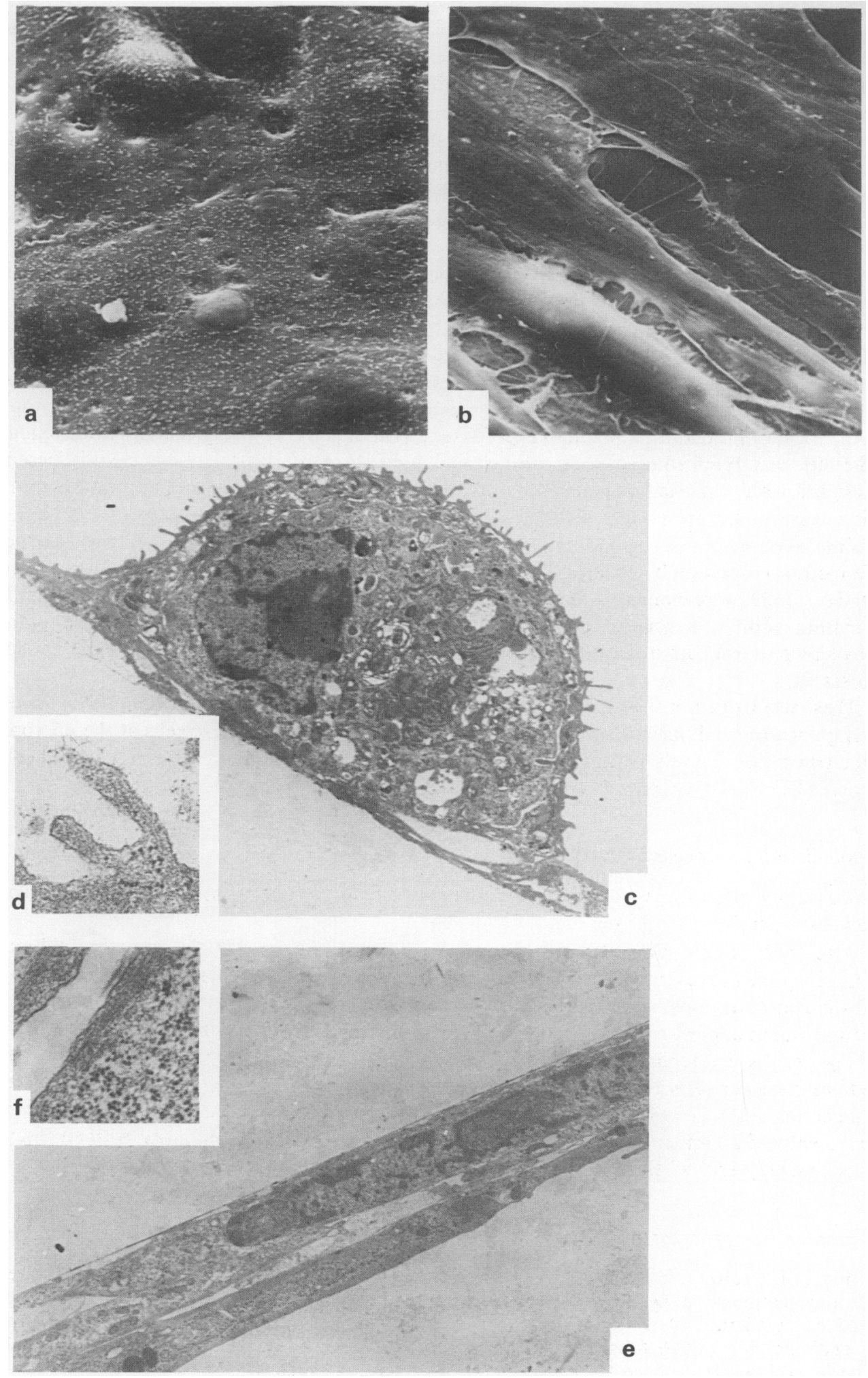
days in the harvest medium containing $10 \%$ dextran-charcoal-pretreated FCS, oestrogen concentrations remained higher than in controls. The metabolism of oestradiol-17 $\beta$ was studied in cells which had been grown for 5 days in growth medium then for 3 days in an oestrogen-free medium; these epithelial cells were then cultured for 3 more days in a fresh medium supplemented with $2 \cdot 5 \%$ horse serum and $2 \times 10^{-9} \mathrm{M}$-oestradiol-17 $\beta$. Oestrone, oestrone sulphate and oestradiol-17 $\beta$ concentrations were measured in fresh harvest medium containing $2 \times 10^{-9} \mathrm{M}$-oestradiol-17 $\beta$, and in the same medium in which the cells had lived during 3 days. As shown in Table 2, in 8 separate experiments, the oestrone concentration in the medium on Day 3 had significantly increased $(P<0.01)$ whereas the increased level of oestrone sulphate was less significant $(P=0.05)$. The release of oestrone and oestrone sulphate in the medium demonstrated that oestradiol-17 $\beta$ was metabolized by epithelial cells in culture, and that $17 \beta$-hydroxysteroid dehydrogenase and sulphotransferase activities persisted. Steroid sulphatase is the third enzyme involved in oestrogen metabolism (Adessi et al., 1981). To test its activity, the oestrone and DHEA sulphatases in cultured endometrial cells were measured before and after 3 days of incubation with $2 \times 10^{-9} \mathrm{M}$-oestradiol-17 $\beta$. Before incubation in the presence of oestradiol-17 $\beta$, the sulphatase activities (pmol product/min per mg DNA) were 211.5 (16.3-657) for oestrone sulphatase and 36.7 (5.4-69.8) for DHEA sulphatase [mean (extreme values)]. After 3 days of culture with $2 \times 10^{-9}$ M-oestradiol-17 $\beta$, these values reached $177 \cdot 2(19 \cdot 4-565 \cdot 3)$ and $62.9(7 \cdot 5-204 \cdot 1)$ respectively.

An important point was to test whether the oestrone sulphatase activity was able to hydrolyse oestrone sulphate in our cell culture conditions. For that purpose, epithelial cells were cultured in fresh medium containing $2.5 \%$ horse serum and $10^{-7} \mathrm{M}$-oestrone sulphate for 3 days, and renewed each day. On Day 3, the unconjugated and conjugated oestrogens were extracted and isolated from the culture medium, then identified by gas chromatography-mass spectrometry. Under these conditions, free oestrone, oestradiol-17 $\beta$ and oestradiol sulphate were identified in the culture medium (Fig. 3).

\section{Effects of oestradiol-17 $\beta$ on cytosolic progesterone receptor amounts in epithelial cell culture}

A monolayer of epithelial cells was obtained after 5 days in growth medium; this experiment

Table 1. Oestrogen concentrations in culture medium

\begin{tabular}{lccc}
\hline & $\begin{array}{c}\text { Oestradiol-17ß } \\
(\mathrm{nmol} / \mathrm{l})\end{array}$ & $\begin{array}{c}\text { Oestrone } \\
(\mathrm{nmol} / \mathrm{l})\end{array}$ & $\begin{array}{c}\text { Oestrone sulphate } \\
(\mathrm{nmol} / \mathrm{l})\end{array}$ \\
\hline Fresh harvest medium & $0.030 \pm 0.014(8)$ & $0.004 \pm 0.003(8)$ & $0.090 \pm 0.014(8)$ \\
On Day 1 & $0.100 \pm 0.020(8)$ & $0.030 \pm 0.010(8)$ & $0.160 \pm 0.007(8)$ \\
On Day 2 & $0.050 \pm 0.010(8)$ & $0.010 \pm 0.007(8)$ & $0 \cdot 120 \pm 0.007(8)$ \\
On Day 3 & $0.030 \pm 0.007(8)$ & $0.004 \pm 0.003(7)$ & $0.070 \pm 0.014(8)$ \\
\hline
\end{tabular}

Values are mean \pm s.d. for the no. of observations in parentheses.

Table 2. Oestrogen metabolism in epithelial cell culture

\begin{tabular}{|c|c|c|c|}
\hline & $\begin{array}{l}\text { Oestradiol-17 } \\
(\mathrm{nmol} / \mathrm{l})\end{array}$ & $\begin{array}{l}\text { Oestrone } \\
(\mathrm{nmol} / \mathrm{l})\end{array}$ & $\begin{array}{l}\text { Oestrone sulphate } \\
(\mathrm{nmol} / \mathrm{l})\end{array}$ \\
\hline $\begin{array}{l}\text { Fresh harvest medium } \\
\text { with } 2 \times 10^{-9} \mathrm{M}- \\
\text { oestradiol-17 }\end{array}$ & $2.030 \pm 0.014(8)$ & $0.004 \pm 0.003(8)$ & $0.090 \pm 0.014(8)$ \\
\hline On Day 3 & $1.420 \pm 0.113(8)$ & $0 \cdot 100 \pm 0.010(8)$ & $0 \cdot 190 \pm 0.040(8)$ \\
\hline
\end{tabular}

Values are mean \pm s.d. for the no. of observations in parentheses. 


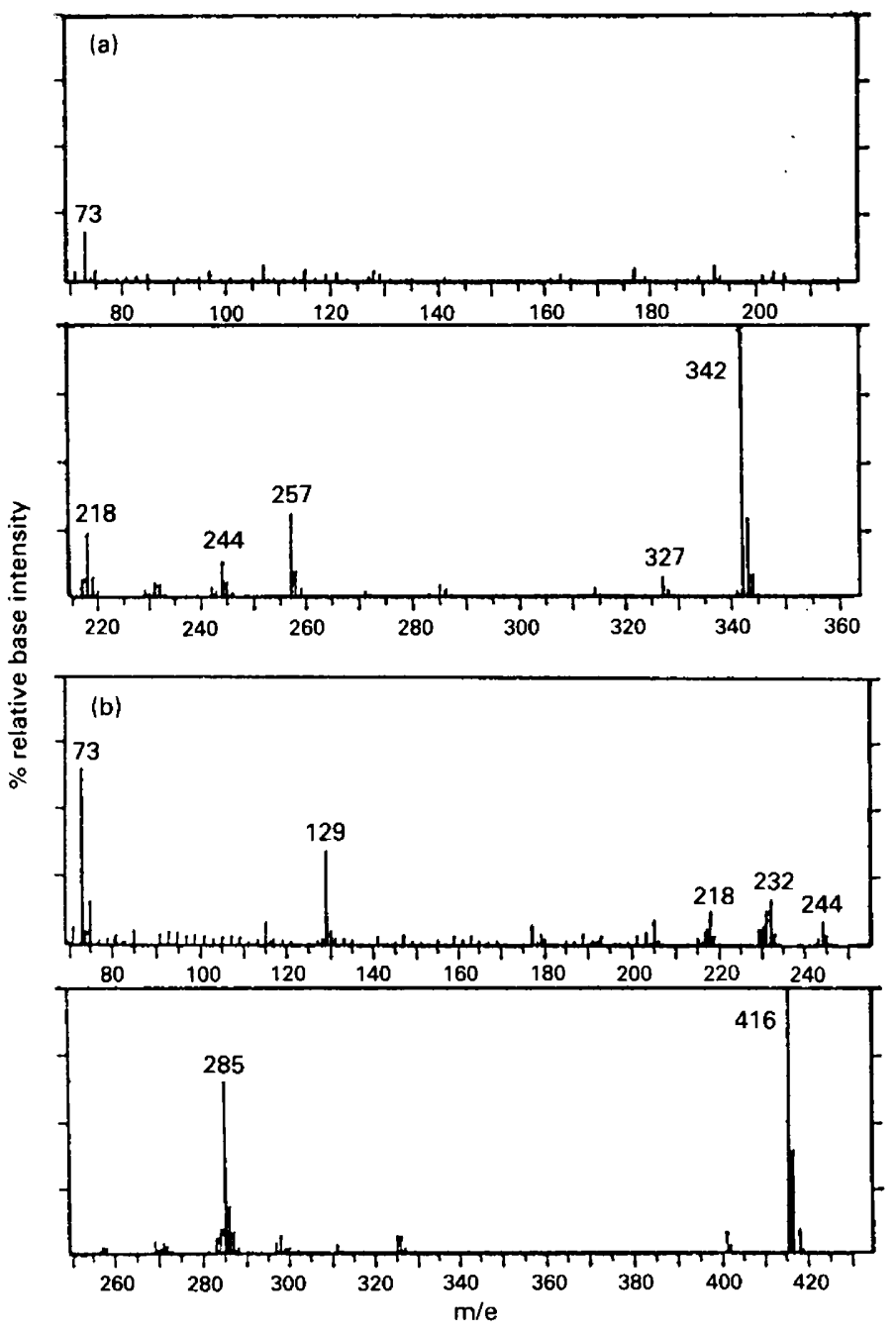

Fig. 3. Identification after 3 days by mass spectrometry of unconjugated and conjugated oestrogens ( $a$, oestrone; $b$, oestradiol-17 $\beta$ ) present in the culture medium, renewed each day, and containing $10^{-7} \mathrm{M}$-oestrone sulphate. The identification of oestradiol-17 $\beta$ in the sulphate fraction reveals the presence of oestradiol sulphate.

required $2 \cdot 3 \pm 0 \cdot 1 \times 10^{7}$ cells per assay. The oestradiol induction was studied in the epithelial cells obtained after 3 days in oestrogen-free medium and the fluid was changed on each of the 3 days. These cells were then incubated in fresh medium containing $2.5 \%$ horse serum and $2 \times 10^{-9} \mathrm{M}$ oestradiol-17 $\beta$ for 3 days. The cells were harvested and homogenized and the amounts of cytoplasmic oestradiol and progesterone receptor were determined by dextran-charcoal assays. Each value represents the average of 6 experiments. Before oestradiol-17 $\beta$ induction, the cytosolic receptor values were $3.58 \pm 1.34$ and $3.60 \pm 1.00 \mathrm{fmol} / \mu \mathrm{g}$ DNA for progesterone and oestradiol respectively. The addition of oestradiol- $17 \beta$ produced an increase in progesterone receptor values to $7.63 \pm 1.10 \mathrm{fmol} / \mu \mathrm{g}$ DNA $(P<0.05)$. The oestrogenic stimulation of the cytosolic progesterone receptors corresponded with a decrease in the cytosolic oestradiol receptor values (to $2 \cdot 37 \pm 0.57 \mathrm{fmol} / \mu \mathrm{g}$ DNA). 


\section{Discussion}

The present study describes a simple and original method for culturing guinea-pig endometrium as separate epithelial and stromal components. The primary epithelial cell cultures described above provide a suitable system for the study of oestrogen metabolism and oestrogen-induced responses.

We have tested two different methods for endometrial cell component isolation. The observations by phase-contrast microscopy, during cell dissociation, show that the method of successive centrifugation described by Varma et al. (1982) is more efficient than that of filtration across a $38 \mu \mathrm{m}$ stainless-steel grid used by Fleming \& Gurpide (1981). The integrity of the glands after digestion by collagenase is better preserved in the first method and the plating efficiency seems to depend on this integrity. If necessary, after separation the pooled gland fraction may be purified from contaminating stromal cells as follows: the epithelial clumps are placed in flasks in culture medium and then incubated at $37^{\circ} \mathrm{C}$ in a $95 \%$ air $-5 \% \mathrm{CO}_{2}$ atmosphere; the residual stromal cells attach selectively to the plastic within $30-45 \mathrm{~min}$, leaving the epithelial glands floating in the medium. The purified epithelial glands are then collected and plated, as described by Kirk \& Irwin (1980).

On Day 5 of the culture, phase-contrast microscopy was used to distinguish the cell types. The flasks containing each type of cells were examined daily. The efficiency of epithelial cell growth in culture seemed to be improved by simple preincubation of the flasks with growth medium which allows the epithelial glands to adhere more quickly. However, the stromal cells attach to the plastic surface more readily and have a fibroblastic appearance. Comparable results have been reported for the rat by Echeverria et al. (1980) and McCormack \& Glasser (1980), for the rabbit by Ricketts et al. (1983) and for the human by Varma et al. (1982). Our preliminary assessment of the two different endometrial components on Day 5 was completed by their characterization with scanning electron microscopy. The features defining the two endometrial cell types are as follows: in epithelial cell culture, the monolayer is composed of polygonal cells with numerous microvilli and a round nucleus, whereas the stromal cells display a typical fibroblastic appearance. Such cultures as we obtained can be clearly categorized as of epithelial or mesenchymal origin. Even at the ultrastructural level, the epithelial cells in vitro display a plasma membrane with microvilli, cytoplasm with electron-dense granules, numerous microtubes and polysomes, abundant rough endoplasmic reticulum and an active nucleus in which the chromatin was mostly extended. In culture, these cells show structural features remarkably similar to those described for endometrial epithelial cells in situ, whereas the stromal cells appear as typical fibroblasts. The third cell type described by Varma et al. (1982) for human endometrium (displaying epithelial cell characteristics by phase-contrast microscopy, but mesenchymal characteristics of stromal cells by transmission electron microscopy) has not been described for the rat (Echeverria et al., 1980), the rabbit (Ricketts et al., 1983) or guinea-pig (present study).

In our study, an important condition was to ensure the complete removal of endogenous steroids before oestrogen stimulation. This is why fresh medium containing $2.5 \%$ horse serum was added on 3 consecutive days; the oestrogen content of horse serum is below the limit which elicits an epithelial cell response (Lee, Davies, Soto \& Sonnenschein, 1981). FCS pretreated by dextrancharcoal has been used for preliminary experiments, but the residual oestrogen level was higher than the threshold of response of the epithelial cells. We have used the steroid-free serum substitute Ultroser SF which is as efficient as horse serum in maintaining healthy cells. After complete removal of endogenous steroids, the incubation with $2 \times 10^{-9} \mathrm{M}$-oestradiol-17 $\beta$ for 3 days shows the persistence of the normal oestrogen metabolism in guinea-pig epithelial cell culture. Indeed, the oestrogen assays after incubation show a conversion of oestradiol-17 $\beta$ to oestrone due to the presence of the 17 $\beta$-hydroxysteroid dehydrogenase still active in cells. Moreover, the oestrone sulphate assay demonstrates that a sulphotransferase activity is also present in cell culture, which converts oestrone into a sulphoconjugated derivative. The oestrone and DHEA sulphatase activities previously characterized by Moutaouakkil et al. (1984) in the uterus and liver of female guinea-pigs have been demonstrated and measured in the epithelial cell culture. The three enzymes 
interfering with oestrogen metabolism are present in our epithelial cell culture and their patterns in epithelial cells cultured in vitro resembled that of fresh endometrium.

The induction of cytosolic progesterone receptors by oestrogen has been studied in rat uterus (Kassis, Sakai, Walent \& Gorski, 1984), in guinea-pig fetal uterus in organ culture (Sumida et al., 1983) and in human endometrial cell culture (Eckert \& Katzenellenbogen, 1981). Our studies indicate that the stimulation of cytosolic progesterone receptor content in primary cultures of guineapig endometrium epithelial cells is a sensitive indicator of its responsiveness to oestradiol-17 $\beta$. In our experiments, the magnitude of the response varied from 1.3 to 10.8 times and oestradiol-17 $\beta$ promoted an apparent dose-dependent depletion of cytosolic oestrogen receptors which may correspond to the accumulation of nuclear oestrogen receptors (Eckert \& Katzenellenbogen, 1981) or to a greater retention of the steroid-receptor complex in the nucleus (Gorski, Welshons \& Sakai, 1984; Stack \& Gorski, 1985). The mass spectrometry study carried out on the culture medium after incubation with oestrone sulphate showed the presence of oestrone, oestradiol-17 $\beta$ and oestradiol sulphate, confirming previous studies. Briefly, extracellular oestrone sulphate is hydrolysed by plasma membrane-bound sulphatase and enters into epithelial cells as unconjugated oestrone. In the endometrial cell, the action of $17 \beta$-hydroxysteroid dehydrogenase leads to the synthesis of oestradiol-17 (Adessi et al., 1982). Conversely, a soluble sulphotransferase converts intracellular free oestrogens into their conjugated derivatives which are inactive metabolites (Adessi et al., 1982). Moreover, the conversion of oestrone sulphate to oestradiol sulphate must arise without prior removal of the sulphate moiety and not by hydrolysis of the oestrogen sulphates followed by resulphurylation (Adessi et al., 1981).

In conclusion, the procedure and results described here for the preparation of primary cultures of the epithelial cells of guinea-pig endometrium provide a system which can be used to study hormone effects on protein synthesis in hormone-responsive endometrial cells in culture.

We thank Myriam David for expert secretarial assistance and Bernadette Montenoise for excellent technical work.

\section{References}

Adessi, G.L., Tran Quang Nhuan \& Prost, O. (1981) The in vitro metabolism of estrone and estradiol- $17 \beta$ and their 3-sulfates by the renal tissues from pregnant and female fetal guinea-pigs. J. Steroid Biochem. 15, 453-459.

Adessi, G.L., Tran Quang Nhuan \& Vingler, P. (1982) In vivo and in vitro metabolism of estrone and estradiol$17 \beta$ and their 3 -sulfates in pregnant female guineapigs: a plausible prehormone role of estrogen-sulfates in the maternal uterus. J. Steroid Biochem. 16, $107-116$.

Adler, K.B., Alberghini, T.V., Counts, D.F. \& Auletta, F.J. (1983) Secretion of mucin by explants of rabbit and human cervix in organ culture. Biol. Reprod. 29, $751-756$.

Bell, S.C. \& Searle, R.F. (1981) Differentiation of decidual cells in mouse endometrial cell cultures. $J$. Reprod. Fert. 61, 425-453.

Burton, K. (1956) A study of the conditions and mechanisms of the diphenylamine reaction for the colorimetric estimation of deoxyribonucleic acid. Biochem. J. 62, 315-323.

Chaminadas, G., Prost, O., Propper, A., Agnani, G. \& Adessi, G.L. (1982) Steroid-sulfatase activities in human endometrium grown in organ culture. Biol. Cell 45, 7 .
Clarke, C.L., Adams, J.B. \& Wren, B.G. (1982) Induction of estrogen sulfotransferase in the human endometrium by progesterone in organ culture. J. clin. Endocr. Metab. 55, 70-75.

Echeverria, O.M., Vazquez-Nin, G.H. \& Pedron, J. (1980) A rapid method for the isolation and culture of endometrial epithelial cells responsive to estradiol. Acta anat. 106, 45-56.

Eckert, R.L. \& Katzenellenbogen, B.S. (1981) Human endometrial cells in primary tissue culture: modulation of progesterone receptor level by natural and synthetic estrogens in vitro. J. clin. Endocr. Metab. 52, 699-708.

Fleming, H. \& Gurpide, E. (1981) Rapid fluctuations in the levels of specific estradiol-binding sites in endometrial cells in culture. Endocrinology 108, 1744-1750.

Gorski, J., Welshons, W. \& Sakai, D. (1984) Remodeling the estrogen receptor model. Molec. cell. Endocr. 36, $11-15$.

Kassis, J.A., Sakai, D., Walent, J.H. \& Gorski, J. (1984) Primary cultures of estrogen-responsive cells from rat uteri: induction of progesterone receptors and a secreted protein. Endocrinology 114, 1558-1566.

Kaufman, D.G., Adamec, T.A., Walton, L.A., Carney, C.H., Melin, S.A., Genta, V.M., Mass, M.J., Dorman, B.H., Rodgers, N.T., Photopulos, G.J., Powell, J. \& 
Grisham, J.W. (1980) Studies of human endometrium in organ culture. In Methods in Cell Biology, Vol. 21 B, pp. 1-27. Eds C. C. Harris, B. F. Trump \& G. D. Stoner. Academic Press, New York.

Kirk, D. \& Irwin, J.C. (1980) Normal human endometrium in cell culture. In Methods in Cell Biology, Vol. 21 B, pp. 52-77. Eds C. C. Harris, B. F. Trump \& G. D. Stoner. Academic Press, New York.

Korte, K., MacDonald, P.C., Johnston, J.M., Janice, R.O. \& Casey, M.L. (1983) Metabolism of arachidonic acid and prostanoids in human endometrial stromal cells in monolayer culture. Biochim. Biophys. Acta 752, 423-433.

Lanzone, A., Nguyen, B.L. \& Pasqualini, J.R. (1983) Uptake, receptor and biological response of estrone in the fetal uterus of guinea-pig. Hormone Res. 17, $168-180$.

Laure, F. \& Pasqualini, J.R. (1983) Effect of estradiol on RNA polymerase of foetal guinea-pig uterus. Experientia 39, 209-210.

Lee, H., Davies, I.J., Soto, A.M. \& Sonnenschein, C. (1981) Estrogen induction of progesterone receptor and its relationship to cell multiplication rate in the rat pituitary tumor cell line $\mathrm{C}_{2}$ 9RAP. Endocrinology 108, 990-995.

McCormack, S.A. \& Glasser, S.R. (1980) Differential response of individual uterine cell types from immature rats treated with estradiol. Endocrinology 106, $1634-1648$.

Moutaouakkil, M., Prost, O., Dahan, N. \& Adessi, G.L. (1984) Estrone and dehydro-epiandrosterone sulfatase activities in guinea-pig uterus in liver: estrogenic effect of estrone sulfate. J. Steroid Biochem. 21, $321-328$.

Prost, O. \& Adessi, G.L. (1983) Estrone and dehydroepiandrosterone sulfatase activities in normal and pathological human endometrium biopsies. $J$. clin. Endocr. Metab. 56, 653-661.

Rajkumar, K., Bigsby, R., Lieberman, R. \& Gerschenson, L.E. (1983) Uteroglobin production by cultured rabbit uterine epithelial cells. Endocrinology 112, 1490-1498.
Remy-Martin, A., Prost, O., Nicollier, M., Burnod, J. \& Adessi, G.L. (1983) Estrone sulfate concentrations in plasma of normal individuals, postmenopausal women with breast cancer and men with cirrhosis. Clin. Chem. 29, 86-89.

Ricketts, A.P., Hagensee, M. \& Bullock, D.W. (1983) Characterization in primary monolayer culture of separated cell types from rabbit endometrium. $J$. Reprod. Fert. 67, 151-160.

Satyaswaroop, P.G., Bressler, P.S., de la Pena, M.M. \& Gurpide, E. (1979) Isolation and culture of human endometrial glands. J. clin. Endocr. Metab. 48, $639-641$.

Satyaswaroop, P.G., Fleming, H., Bressler, R.S. \& Gurpide, E. (1978) Human endometrial cancer cell culture for hormonal studies. Cancer Res. 38, $4367-4375$.

Shapiro, S.S., Dyer, R.D. \& Colas, A.E. (1980) Progesterone-induced glycogen accumulation in human endometrium during organ culture. Am. J. Obstet. Gynecol. 136, 419-425.

Siegfried, J.M., Nelson, K.G., Martin, J.L. \& Kaufman, D.G. (1984) Histochemical identification of cultured cells from human endometrium. In vitro 20, 25-32.

Stack, G.P. \& Gorski, J. (1985) Relationship of estrogen receptors and protein synthesis to the mitogenic effect of estrogens. Endocrinology 117, 2024-2032.

Sumida, C., Gelly, C. \& Pasqualini, J.R. (1983) De novo synthesis of progesterone receptor in the fetal uterus of guinea-pig in organ culture and its control by progestins and triphenylethylene antiestrogens. Biochim. Biophys. Acta 755, 488-496.

Tseng, L. (1984) Effect of estradiol and progesterone on human endometrial aromatase activity in primary cell culture. Endocrinology 115, 833-835.

Varma, V.A., Melin, S.A., Adamec, T.A., Dorman, B.H., Siegfried, J.M., Walton, L.A., Carney, C.N., Norton, C.R. \& Kaufman, D.G. (1982) Monolayer culture of human endometrium: methods of culture and identification of cell types. In vitro 18, $911-918$.

Received 28 October 1985 